\section{Arbovirus en Latinoamérica}

Arredondo-García JL¹, Méndez-Herrera $\mathrm{A}^{2}$, Medina-Cortina $\mathrm{H}^{2}$

\section{Resumen}

Las enfermedades producidas por arbovirus son un problema muy grave a nivel mundial, debido a que su vigilancia y prevención implica también la vigilancia de sus vectores, lo que hace difícil su control y casi imposible evitar su expansión a cualquier país tropical o subtropical, e incluso algunas regiones templadas. A nivel mundial, el dengue es la enfermedad por arbovirus más común con $40 \%$ de la población mundial viviendo en zonas de transmisión del virus del dengue. De las 390 millones de infecciones estimadas y 100 millones de casos anuales, una proporción pequeña de estos casos progresa a dengue grave. Aproximadamente uno de cada 2,000 casos de dengue causan la muerte; sin embargo, la tasa de letalidad de los pacientes con dengue grave se puede reducir de casi $10 \%$ a menos del $0.1 \%$ si se actúa rápidamente y con calidad en la atención clínica que reciben los pacientes. Esto, aunado a la reciente y rápida propagación del virus chikungunya y el brote de virus zika en países latinoamericanos, como México, hace necesaria la actualización médica y revisión de bibliografía respecto a la prevención, control y gestión de las infecciones causadas por arbovirus. Por lo tanto, presentamos una revisión de lo más reciente sobre enfermedades por arbovirus en América Latina.

PALABRAS CLAVE: Dengue, Zika, Chikungunya, Arbovirus, Aedes.

Acta Pediatr Mex. 2016 Mar;37(2):111-131.

\section{Arbovirus in Latin America}

Arredondo-García JL¹, Méndez-Herrera A², Medina-Cortina $\mathrm{H}^{2}$

\section{Abstract}

Diseases produced by arboviruses are a major worldwide problem due to the fact that the surveillance and prevention of them implies the surveillance of vectors, which makes it very difficult to control them, and almost impossible to avoid their expansion to any tropical or subtropical country, and even some temperate regions. Globally, dengue is the most common arboviral disease, with $40 \%$ of the world population living in areas with dengue virus transmission. Of the estimated 390 million infections and 100 million cases annually, a small proportion of these cases progress to severe dengue. Approximately one in 2,000 dengue cases result in death. However, the case-fatality rate of patients with severe dengue can be reduced from almost $10 \%$ to less than $0.1 \%$ by the timing and quality of clinical care that patients receive. This, coupled with the recent and quick spread of Chikungunya virus and the outbreak of Zika virus in Latin American countries including Mexico, makes it necessary the medical update and review of bibliography concerning the prevention, control and management of arboviral-caused diseases. Therefore we present a review of the most recent literature on arboviral diseases in Latin America.

KEY WORDS: Dengue; zika; chikungunya; arbovirus; Aedes
${ }^{1}$ Médico Pediatra Infectólogo, Subdirector de Investigación Médica.

${ }^{2}$ Investigador, Unidad de Apoyo a la Investigación Clínica.

Instituto Nacional de Pediatría.

Recibido: 5 de febrero del 2016

Aceptado: 7 de marzo del 2016

Correspondencia

Dr. José Luis Arredondo García

Subdirector de Investigación Médica

Instituto Nacional de Pediatría

Insurgentes Sur 3700-C

04530 Ciudad de México

Tel. 10840900 ext. 1137-1901

joselag@unam.mx

arredondo.joseluis@gmail.com

Este artículo debe citarse como

Arredondo-García JL, Méndez-Herrera A, MedinaCortina H. Arbovirus en Latinoamérica. Acta Pediatr Mex. 2016;37(2):111-131. 


\section{INTRODUCCIÓN}

Los arbovirus son, como lo describió la Organización Mundial de la Salud en 1967, un grupo de virus que existen en la naturaleza principalmente, debido a la transmisión biológica entre huéspedes vertebrados susceptibles por artrópodos hematófagos; de ahí su nombre del inglés "Arthropod-Borne Viruses" o "Virus Ilevados (transmitidos) por artrópodos". Es precisamente debido a que su vigilancia requiere la guardia de los vectores que las enfermedades causadas por arbovirus son difíciles de prevenir y controlar. Los arbovirus son un grupo taxonómicamente heterogéneo de más de 500 virus; de éstos, aproximadamente 150 causan enfermedad en el hombre. ${ }^{1-3}$

Se dividen en 3 familias principalmente y otra manera de clasificarlos es de acuerdo al tipo de síndrome que ocasionan en el ser humano ${ }^{3}$ (Figuras 1 y 2 ).

\section{VECTORES}

Los arbovirus son transmitidos por una gran variedad de vectores como mosquitos, garra-

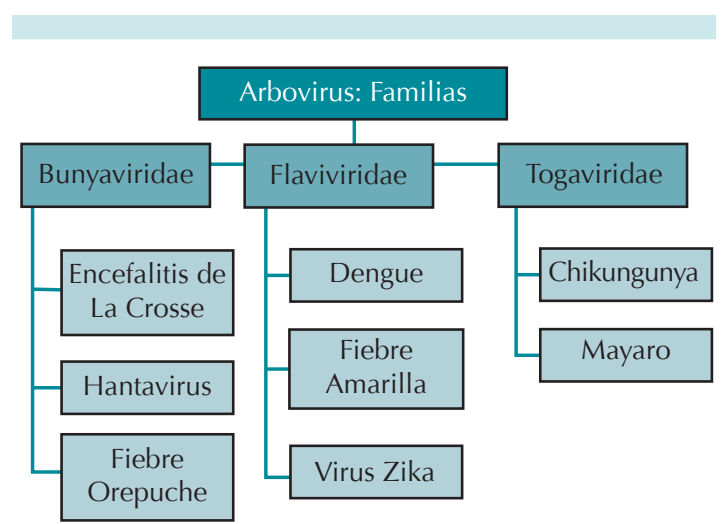

Figura 1. Familias pertenecientes al grupo Arbovirus. Fuente: Navarrete-Espinosa J, Gómez-Dantés H. Arbovirus causales de fiebre hemorrágico en pacientes del Instituto Mexicano del Seguro Social. Rev Med Inst Mex Seguro Soc 2006;44(4):347-353.

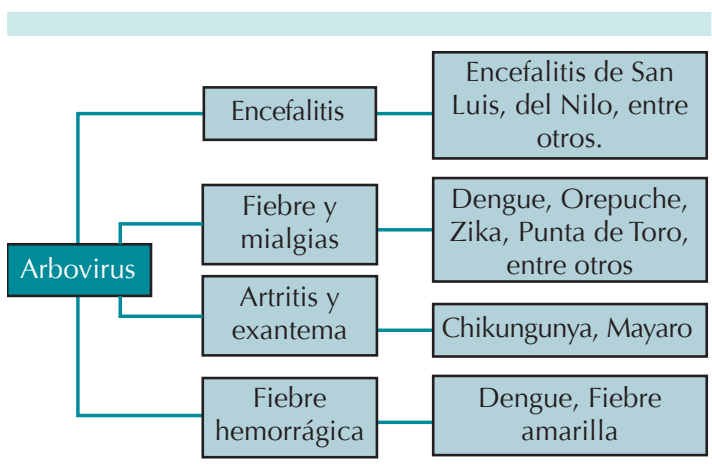

Figura 2. Clasificación según el síndrome que causa. Fuente: Navarrete-Espinosa J, Gómez-Dantés H. Arbovirus causales de fiebre hemorrágico en pacientes del Instituto Mexicano del Seguro Social. Rev Med Inst Mex Seguro Soc 2006;44(4):347-353.

patas, pulgas, entre otros. En esta revisión nos enfocaremos en aquellos arbovirus transmitidos por mosquitos y que afectan predominantemente el territorio latinoamericano. ${ }^{2}$ Los principales vectores de dengue y chikungunya son los culícidos pertenecientes al género Aedes como Ae. aegypti y Ae. albopictus; sin embargo, el virus del dengue también se ha encontrado en otras especies como Ae. poliniensis, Ae. mediovitattus y Ae. nivalis. En cambio, el Ae. vigilax está confirmado como un transmisor efectivo del virus de chikungunya. ${ }^{4,5}$

Se cree que el Ae. aegypti arribó de África a América con la llegada de los primeros europeos al continente americano. Los primeros brotes de la enfermedad por dengue en la región de las Américas datan de 1635. El Ae. albopictus también es un eficiente vector de arbovirus en Asia suroriental y apareció en el continente americano por primera vez en Estados Unidos en 1985. También se ha identificado en varios países latinoamericanos incluyendo México y aunque su presencia no se ha relacionado con el aumento de la transmisión de arbovirus, cabe mencionar que el Ae. albopictus puede actuar como vector en áreas urbanas y rurales, y no es antropofílico obligatorio, como Ae. aegypti, por 
lo que en ocasiones este último es desplazado de su hábitat. ${ }^{6}$

Las hembras de Ae. aegypti se consideran las más eficientes de los mosquitos vectores por sus marcados hábitos domésticos, que satisfacen todas sus necesidades vitales en la vivienda humana. La hembra requiere sangre humana para mantener su reproducción; pone sus huevos en depósitos de agua limpia o semi-limpia, lo cual es un dato importante para su control, ya que los criaderos viables para el mosquito son todos esos objetos que sirven como recipientes donde se colecta el agua de lluvia. ${ }^{7,8}$

En 1957 se realizó una campaña antivectorial para su eliminación, objetivo que se cumplió en 1963, cuando la Organización Panamericana de la Salud declaró su erradicación del país. Sin embargo, esta situación sólo pudo ser mantenida durante dos décadas, periodo dentro del cual hubo una reinfestación paulatina del territorio nacional. No obstante, a pesar de que el país duró solamente dos años sin el mosquito, no hubo ningún caso publicado de dengue hasta su reemergencia en 1978. El patrón de diseminación ha sido de Sur a Norte a lo largo de los estados del sureste y Golfo de México a la mayoría de las entidades de la república. ${ }^{6}$ Este fenómeno ha sido determinado por factores sociales y económicos, así como ambientales que inciden directamente en la evolución y mecanismos de adaptación de diferentes vectores. Entre de estos factores están: el cambio climático, ya que se sabe que el incremento de 1 a 2 grados en la temperatura global puede influir en la extensión de las áreas geográficas donde se desarrollan los insectos; el crecimiento poblacional, pues se estima que para el año 2020 el 80\% de la población se concentrará en las ciudades, situación que en 1954 era apenas del 50\%. Esto, aunado a la deforestación y urbanización deficiente que casi siempre va acompañada de falta de agua potable y que obliga a los habi- tantes a almacenar este líquido en recipientes y otros recipientes mal cubiertos o expuestos a la intemperie, favorece la reproducción de estos insectos; la disposición inadecuada de desechos sólidos y líquidos, pobres condiciones de vivienda, así como abundantes vectores; la migración, viajes turísticos y la mayor velocidad con la que se transporta actualmente la población hacen que millones de personas crucen fronteras cada año favoreciendo la circulación del virus desde las áreas endémicas hasta las áreas libres de enfermedad. ${ }^{7}$

\section{DENGUE}

\section{Generalidades}

El virus del dengue es un Flavivirus de la familia Flaviviridae, existen cuatro serotipos de dengue, cada uno genera una respuesta inmunitaria a la infección única en el hospedero, distribuidos a lo largo de las regiones tropicales y subtropicales de todo el mundo y de algunas regiones templadas de Estados Unidos, Europa, África y Medio Oriente. Estos cuatro serotipos son genéticamente similares, comparten aproximadamente $65 \%$ de su genoma y son transmitidos a primates no humanos (forma selvática) y humanos (forma humana) principalmente por el mosquito del género Aedes. Los virus del dengue selváticos son evolutiva y ecológicamente distinguibles de los virus del dengue humanos. Episodios esporádicos de infecciones selváticas en humanos en Asia y África sugieren que los virus del dengue selváticos regularmente entran en contacto con seres humanos. Se tenía el temor de que los virus del dengue selváticos pudieran interferir con la inmunidad de las vacunas en desarrollo; sin embargo, se ha comprobado que hay una robusta inmunidad cruzada homotípica de serotipo entre las cepas selváticas y humanas. No obstante, existen informes de un $5^{\circ}$ serotipo durante un brote en Malasia en el año 2007. Al principio se pensaba que era una variante del 
serotipo 4; sin embargo, cuando unos simios Rhesus, a los cuales se había pre-infectado con los otros 4 serotipos y se habían recuperado ya, se infectaron con el serotipo DENV-5 produjeron una significativa y diferente gama de anticuerpos. Esto podría ser problemático para las vacunas tetravalentes que están en tercera fase de desarroIlo. La buena noticia es que esta nueva variante aún no se ha establecido como tal en el ciclo de transmisión humana y se piensa que sea una forma selvática. ${ }^{9-13}$

El virión tiene diez proteínas: central, membranal, una glucoproteína de envoltura y siete proteínas no estructurales. El virus tiene forma esférica y un diámetro aproximado de $50 \mathrm{~nm}$. El genoma viral consiste en una cadena sencilla de ARN de polaridad positiva. Las propiedades inmunológicas y antigénicas del virus están dadas por antígenos estructurales $(\mathrm{P}, \mathrm{M}, \mathrm{E})$ y no estructurales (NS1 a NS5) 6,14 (Figura 3).

\section{Patogenia}

Las hembras de Aedes adquieren el virus al picar a un hospedero vertebrado virémico. El virus infecta las células epiteliales del intestino medio del mosquito, se disemina hacia la circulación e infecta las glándulas salivales; en este sitio se

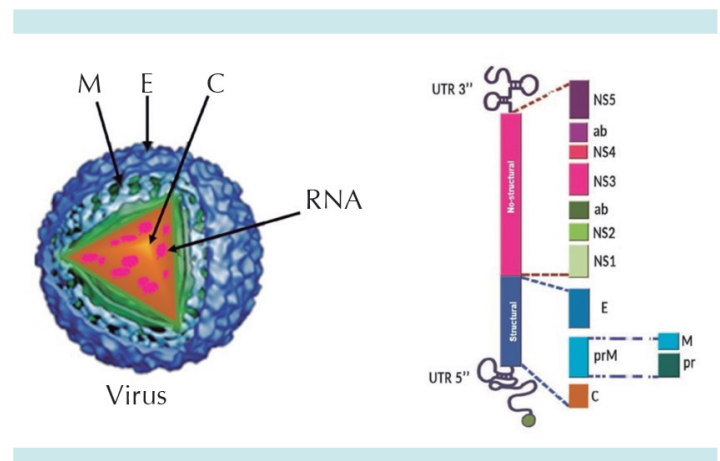

Figura 3. Estructura molecular del virus del dengue. Modificado de: Angel RMd, Valle JR-d. Dengue Vaccines: Strongly Sought but Not a Reality Just Yet. PLoSPathog. 2013;9(10):e1003551. establece una infección persistente con replicación importante en estas células. Tras picar al hospedero, la hembra del mosquito regurgita saliva llena de virus a la sangre de la víctima. El virus circula libre por el plasma y entra en contacto con células susceptibles, tales como células endoteliales, macrófagos, monocitos y otras células del sistema fagocítico mononuclear. El sistema inmunológico innato es la primera línea de defensa en contra de virus del dengue y la infección desencadena la expresión de una amplia gama de citocinas y quimiocinas proinflamatorias (también antiinflamatorias).

En la infección por dengue se reconocen cuatro fases: fase de incubación, que dura de tres a diez días; fase febril, que se mantiene de dos a siete días; la fase crítica (fuga plasmática) se presenta entre el tercer y séptimo días de inicio de la fiebre; y la fase de recuperación (reabsorción de líquidos) que ocurre entre el séptimo y décimo días. La mayoría de los enfermos desarrolla la forma leve o fiebre por dengue y algunos la forma hemorrágica, que puede llevar a la muerte cuando se acompaña del síndrome de choque por dengue. Se ha documentado que con mayor frecuencia los individuos que sufren las formas graves han tenido una infección anterior por un serotipo diferente del virus. Esto se debe a que los anticuerpos de la infección primaria se unen al virus de la infección secundaria y forman un complejo que es fagocitado por los macrófagos, situación que ocasiona que más células resulten infectadas y se liberen mayores cantidades de citocinas y mediadores químicos, los cuales incrementan la permeabilidad vascular. Además, se ha comprobado que las infecciones secundarias suprimen la inmunidad innata anti-virus del dengue como los radicales de óxido nítrico al bloquear la transcripción del factor de transcripción del gen de iNOS, IRF-1, y bloquear la activación de STAT-1. También se suprime significativamente la actividad de la IL-12 y el IFN-Y, lo que aumenta la carga viral. En cambio, en la infección primaria por virus del dengue, la re- 
plicación del virus en los monocitos/macrófagos está limitada debido a una actividad intracelular efectiva anti-virus del dengue, lo que causa en una baja carga viral. No obstante casos graves también ocurren por infección primaria lo que depende principalmente del serotipo.

El riesgo de dengue hemorrágico es mayor en caso del serotipo DEN-2, seguido de DEN-3, DEN-4 y DEN-1. Los individuos infectados con un serotipo mantienen una memoria inmunológica prolongada que provee de protección de por vida contra el serotipo infectante (protección homotípica), mientras la protección cruzada en contra de los otros serotipos (protección heterotípica) dura, en promedio, tres meses hasta tres años, después de la cual son completamente susceptibles a la infección con los otros 3 serotipos. Desde luego, la manifestación de la enfermedad depende también de otros factores tales como la raza, la edad, la respuesta inmunitaria, entre otros. Los anticuerpos de infecciones primarias son en su mayor parte de la clase IgM y están dirigidos principalmente contra los determinantes antigénicos específicos del virus del dengue. Las infecciones secundarias inducen anticuerpos IgG dirigidos contra los antígenos del grupo flavivirus. Después del corto periodo de protección cruzada luego de una infección primaria, hay más riesgo de enfermedad grave, resultado de una infección secundaria heteróloga.

Los complejos antígeno-anticuerpo que se forman durante una infección secundaria facilitan la infección de nuevas células mononucleares mediante receptores $\mathrm{FC}_{\gamma}$. Los monocitos infectados se vuelven blanco de los mecanismos inmunitarios y al ser atacados liberan los mediadores químicos que aumenta la permeabilidad capilar, activan al complemento, liberan trombloplastina y en conjunto provocan los cambios fisiopatológicos de la fiebre hemorrágica por dengue. A mayor número de células infectadas, mayor severidad en las manifestaciones clínicas de la enfermedad. ${ }^{6,15-7}$

\section{Epidemiología}

El dengue es una de las enfermedades reemergentes más importantes del mundo actual ya que origina entre 50 y 100 millones de casos anuales en más de 100 países. En la mayoría de éstos se manifiesta como un cuadro gripal o febril indiferenciado y en más de 500 mil pacientes, como dengue hemorrágico. Causa alrededor de 24 mil defunciones al año, gran parte en niños. En 1970 sólo nueve países habían sufrido epidemias de dengue hemorrágico, cifra que para 1995 se había cuadriplicado. Actualmente, la enfermedad es endémica en más de 100 países de África, América, Mediterráneo Oriental, Asia Sudoriental y el Pacífico Occidental. Antes de 1981 el dengue era considerado un problema de salud pública del continente asiático. Este escenario cambió repentinamente como resultado de la epidemia cubana de 1981, que fue la primera epidemia de dengue hemorrágico en América. Actualmente es la enfermedad reemergente más importante en el continente americano $^{6}$ (Cuadro 1).

En el informe de la Organización Panamericana de la Salud de la semana epidemiológica 45 del 2015, sobre casos de dengue y dengue grave descritos, se aprecia a México en tercer lugar con 196,601 casos, justo después de Colombia y Brasil. En la región de Norteamérica y Centroamérica, México es el país con más casos informados, seguido de El Salvador y Honduras. Acerca de los casos de dengue grave, la Organización Panamericana de la Salud señala a México con el mayor número de casos en América, probablemente por ser uno de los pocos países con cuatro serotipos de virus del dengue en circulación. ${ }^{18-9}$ Los países que presentan cocirculación de los cuatro serotipos son: México, Guatemala, Nicaragua, Colombia, Venezuela, Guyana Francesa, Guadalupe, Brasil, Perú y Argentina ${ }^{20}$ (Figura 4). 
Cuadro 1. Incidencia de infecciones por virus del dengue en América a la semana 45 del 2015

\begin{tabular}{lccccc}
\hline Subregiones & Dengue & $\begin{array}{c}\text { Tasa incidencia } \mathbf{x ~ 1 0 0 , 0 0 0} \\
\text { habitantes }\end{array}$ & $\begin{array}{c}\text { Dengue } \\
\text { grave }\end{array}$ & $\begin{array}{c}\text { Muertes } \\
\text { Tasa de } \\
\text { letalidad }\end{array}$ \\
$\begin{array}{lcccc}\text { Norteamérica, Centroamérica } \\
\text { y México }\end{array}$ & 350,017 & 208.7 & 5,365 & 53 & 0.02 \\
Andina & 177,855 & 129.2 & 1,342 & 120 & 0.07 \\
Cono Sur & $1,573,643$ & 610.6 & 1,496 & 814 & 0.05 \\
Caribe hispano & 14,769 & 58.0 & 89 & 89 & 0.60 \\
Caribe inglés y francés & 2,355 & 12.4 & 0 & 0 & 0.00 \\
Total & $2,118,639$ & 348.7 & 8,292 & 1,076 & 0.05
\end{tabular}

Número de casos reportados de dengue y dengue grave en América, Organización Panamericana de la Salud, 2015.

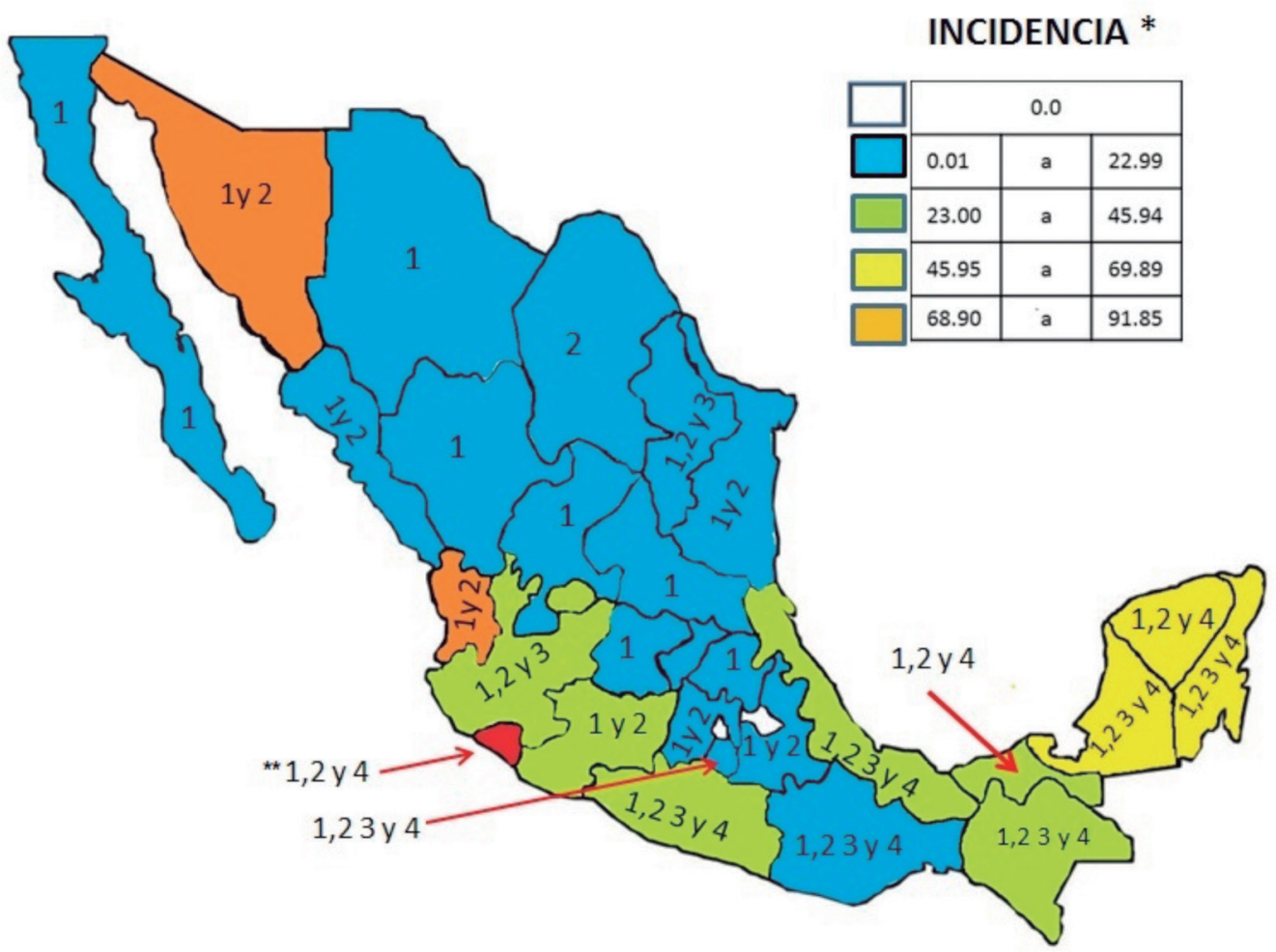

El estado de colima presenta la Incidencia mas alta 158.27

* Incidencia de Casos por FD y FHD por 100 mil habitantes

${ }^{* \star}$ Número de Serotipos

Figura 4. Serotipos identificados por reacción en cadena de la polimerasa con transcriptasa inversa en tiempo real e incidencia de casos estimados por entidad federativa, México, 2015. Modificado de: SINAVE/DGE/SALUD/ Sistema Especial de Vigilancia Epidemiológica de Dengue. 


\section{Manifestaciones clínicas}

El dengue tiene varios patrones de presentación clínica con progresión y desenlaces impredecibles, desde formas asintomáticas hasta sangrado grave y shock, resultando en la muerte. La reinfección con un serotipo diferente está asociada con las manifestaciones clínicas graves, debido a la reacción cruzada por anticuerpos. La primera manifestación clínica del dengue es la instauración súbita de fiebre, usualmente de $39-40^{\circ} \mathrm{C}$, acompañada de cefalea, postración, mialgias, artralgias, dolor retro-orbital, prurito y exantema. Adicionalmente, puede haber anorexia, náusea, vómito y diarrea. Los síntomas iniciales de dengue grave son similares a los de la forma clásica, rápidamente seguidos de sangrado y/o derrame de cavidad, inestabilidad hemodinámica y shock. Las manifestaciones hemorrágicas se acompañan de trombocitopenia $(<100,000$ plaquetas $/ \mathrm{mm}^{3}$ ), hemoconcentración y uno o más eventos clínicos indicativos de extravasación plasmática: derrame pleural, ascitis y un incremento del hematócrito arriba del 20\% del valor basal. La pérdida selectiva de plasma en las cavidades serosas, como la peritoneal y pleural, pueden causar shock hipovolémico. Las manifestaciones hemorrágicas comienzan de tres a siete días después del inicio de la enfermedad, caracterizadas por una prueba de torniquete positiva, petequias, equimosis, epistaxis, gingivorragia, sangrado uterino y sangrado de tubo digestivo alto. En el dengue grave, una fiebre elevada puede durar de dos a siete días, y entonces los pacientes pueden desarrollar dolor abdominal intenso, palidez, piel fría, agitación, insomnio, dificultad para respirar, pulso rápido y débil, shock y la muerte. ${ }^{21}$

En los niños, el dengue puede ser asintomático o polisintomático, lo que dificulta el diagnóstico diferencial. ${ }^{22}$ Se ha observado que los pacientes pediátricos son más propensos a desarrollar shock debido a su micro-vasculatura mucho más permeable. La cefalea, melena, petequias, dolor retro-orbital, mialgias, artralgias, náuseas y los vómitos son mucho más frecuentes en adultos, en contraste con la ocurrencia más frecuente de epistaxis, oliguria y hepatomegalia en niños. Los casos más severos de dengue se presentan en los niños más grandes y en los adultos con infección por algún virus heterólogo. Sin embargo, la fiebre hemorrágica por dengue y el síndrome de shock por dengue también se presentan durante la infancia temprana en niños con infección primaria por virus del dengue. ${ }^{23-4}$ Varias formas de daño renal han sido identificadas en pacientes con dengue, incluyendo elevación de los niveles de creatinina, daño renal agudo, síndrome urémico hemolítico, proteinuria, glomerulopatía y síndrome nefrótico. El dengue causa manifestaciones neurológicas en 3 a $6 \%$ de los casos, pero la presentación de síntomas o signos neurológicos es infrecuente; aún así, se han descrito numerosas manifestaciones neurológicas relacionadas con el dengue como encefalopatía, encefalitis, síndrome de Guillain-Barré, mielitis transversa y encefalomielitis diseminada aguda..$^{21,25}$

\section{Hallazgos de laboratorio}

La trombocitopenia $\left(<150,000\right.$ plaquetas $\left./ \mathrm{mm}^{3}\right)$ es la anormalidad hematológica más frecuente, está presente en $90 \%$ de los pacientes y plaquetas $<100,000$ en el $78 \%$, seguida de leucopenia $\left(<4,000\right.$ leucocitos $\left./ \mathrm{mm}^{3}\right)$, relativa linfocitosis en $60-80 \%$ y en el dengue grave hematocrito incrementado. Se ha observado trastorno de la función hepática en aproximadamente 90\% de los pacientes con elevación de las transaminasas. Una característica del trastorno hepático debido a infección por virus del dengue es la mayor elevación de la AST en comparación con la ALT. Entre las anormalidades electrolíticas la más frecuente es la hiponatremia. Adicionalmente, los pacientes pueden tener las pruebas de coagulación anormales, niveles incrementados de urea y creatinina, bajos niveles de complemento (C3) 
y alteraciones de la orina: proteinuria, hematuria y leucocituria. ${ }^{21,26-7}$

\section{Diagnóstico}

Existen diversas técnicas de laboratorio convencionales para el diagnóstico de dengue, una es el aislamiento del virus, considerado como referente de oro; sin embargo, su uso es limitado por ser laborioso, caro y por requerir equipo muy especializado. Alternativamente, la reacción en cadena de la polimerasa con transcriptasa inversa se puede utilizar para la detección de ARN viral durante las etapas tempranas de la infección es una técnica rápida y sensitiva aunque se requiere habilidad técnica y un laboratorio avanzado para su uso. Debido a esto, los ensayos serológicos son las técnicas más populares y utilizadas por ser comparativamente baratas, sensibles, rápidas y por contar con reactivos de larga vida útil. Entre estos ensayos el NS1 ELISA es quizá una alternativa más útil que la reacción en cadena de la polimerasa durante la fase aguda del dengue, mientras que ELISA específico para IgM permanece como una buena opción durante el periodo de convalecencia. Sus únicos inconvenientes es que son tardados, no adaptables a la detección en tiempo real; requieren personal capacitado y maquinaria cara y voluminosa. El desarrollo de ensayos biosensores podrían superar las limitaciones del ELISA ya que la tecnología biosensora tiene sensibilidad similar o incluso más alta con la ventaja de portabilidad y miniaturización, además de ser fácil de usar y barata en comparación; sin embargo, aún queda un camino largo para su comercialización. ${ }^{28}$

\section{Tratamiento}

El tratamiento sintomático y de soporte incluye reposo y el uso de acetaminofén o paracetamol para el alivio de la fiebre y el dolor, y no se recomienda el uso de antiinflamatorios no esteroideos debido al riesgo de sangrado. $\mathrm{Ni}$ de aspirina por el riesgo a desarrollar síndrome de Reye en niños menores de 12 años de edad. Se debe aconsejar a los pacientes beber grandes cantidades de líquidos para reponer las pérdidas por sudoración, vómitos y otras pérdidas insensibles. El tratamiento actual continúa enfocándose en el cuidado de soporte. En la fase crítica de la fiebre por dengue la supervisión cercana, detección temprana y manejo oportuno son las claves para un tratamiento exitoso. Los cristaloides son la opción terapéutica preferida debido a su eficacia, bajo costo y amplia disponibilidad, ya que no se ha visto evidencia que el uso de coloides sea superior a estos. Sin embargo, si no hay respuesta a la terapia con cristaloides, a pesar de una adecuada resucitación, es obligatorio cambiar al uso de coloides. Si la fuga lleva a edema pulmonar, la adición de un vasopresor como norepinefrina puede ser considerada. Después de estabilizar hemodinámica y clínicamente al paciente, el médico tratante debe saber cuando reducir y descontinuar los líquidos para evitar la congestión y otras complicaciones. Por otro lado, el desarrollo de intervenciones terapéuticas dirigidas al dengue sintomático, más que al síndrome de shock por dengue, se ha convertido en el mayor enfoque de la investigación actual. ${ }^{29-31}$

Existe considerable interés en la utilidad potencial de agentes antivirales. Actualmente, se encuentran en desarrollo numerosos compuestos que tienen como blanco numerosas proteínas tanto del hospedero como del virus, pero sólo unos pocos agentes han llegado a ensayos clínicos en humanos con infección por dengue. La cloroquina, el balapavir y el celgosivir. Desafortunadamente, aunque se ha constatado la seguridad de estos compuestos, no hay evidencia en los ensayos de algún beneficio en reducir la viremia o prevenir el desarrollo de complicaciones. ${ }^{29}$

Otros agentes en investigación como terapia para el dengue son el grupo de las estatinas, ya 
que hay lípidos específicos de múltiples clases que son esenciales en cada paso del ciclo de replicación de la familia Flaviviridae, incluyendo la entrada viral, traducción y replicación del genoma viral, así como el ensamblaje y egreso de la progenie de viriones. La capacidad de las estatinas para inhibir la replicación viral in vitro dio paso a ensayos clínicos con resultados contradictorios, Recientemente se publicó el resultado de un ensayo clínico fase I en el que se estableció que el tratamiento con lovastatina en 300 adultos con dengue es seguro y bien tolerado. Sin embargo, aunque el estudio no estaba diseñado para valorar eficacia, no se encontró evidencia de efectos benéficos en las manifestaciones clínicas o en la viremia. ${ }^{32-3}$ Otros de los agentes en investigación que siguen en etapas preclínicas pero han mostrado disminuir la replicación viral o la viremia son: el inhibidor del proteosoma bortezomib, la ribavirina y el compuesto A. ${ }^{34-5}$

La evidencia del uso de corticosteroides en el dengue es inconclusa y la calidad de la evidencia es muy baja. Esto se aplica para el uso de esteroides en el síndrome de shock por dengue y el dengue en etapas tempranas. Aunque se ha constatado que la terapia con prednisolona, en etapas tempranas del dengue en niños, con una dosis de $2 \mathrm{mg} / \mathrm{kg}$ es segura y el único efecto adverso encontrado es una tendencia a la hiperglucemia, no se demostró evidencia de prevención del síndrome de shock por dengue. Curiosamente, la falla de la prednisolona en mostrar beneficios tanto clínicos como de laboratorio deja la puerta abierta a la hipótesis de que los mastocitos juegan un rol importante en la patogénesis del dengue, ya que este tipo de esteroides no tienen efecto sobre la degranulación de los mastocitos. ${ }^{29,36}$

La trombocitopenia es frecuente en el paciente con dengue, pero rara vez se ve acompañada de sangrado clínico abundante. La transfusión de plaquetas es muy frecuente, sin embargo, a pesar de una falta de evidencia de beneficios, costo significativo, riesgo de sobrecarga hídrica, reacciones alérgicas y transmisión de patógenos. Una publicación reciente de pacientes con dengue y cuenta plaquetaria menor de 30,000/ $\mathrm{Ll}$, concluyó que la administración de plaquetas no previno el sangrado grave ni acortó el tiempo de sangrado, y causó daño significativo. La hemorragia grave interna o externa debe ser tratada con transfusión de 5-10 mL/kg de paquetes globulares o $10-20 \mathrm{~mL} / \mathrm{kg}$ de sangre total. ${ }^{29,37}$

La vacuna contra el dengue CYD-TDV, que tiene una eficacia del $64.7 \%$ para prevenir dengue, $80.3 \%$ para prevenir hospitalización por dengue y $95.5 \%$ para prevenir casos de dengue grave, ha sido aprobada recientemente en México para su comercialización. Esta vacuna puede prevenir más de 8,000 hospitalizaciones, 104 muertes anuales y generar ahorros por 1,100 millones de pesos anuales por atención médica ${ }^{10,38}$ (Figura 5).

\section{CHIKUNGUNYA}

\section{Generalidades}

La fiebre chikungunya es una enfermedad emergente transmitida por mosquitos y que desde el año 2004 ha causado grandes epidemias, provocando considerable morbilidad y sufrimiento. El nombre chikungunya deriva de una palabra en Makonde, el idioma que habla el grupo étnico de Makonde, al sudeste de Tanzania, y significa a grandes rasgos "hombre encorvado" y describe la postura inclinada de quienes padecen esta afectación y dolorosa artralgia. El chikungunya es un virus ARN perteneciente al género Alphavirus de la familia Togaviridae, está constituido por una hebra positiva de ARN. Su genoma codifica tres proteínas estructurales (C, E1 y E2) y cuatro no estructurales (nsP1-4). Su cápside tiene forma de ostra y posee dos glicoproteínas virales: E1 y E2, de gran importancia para el reconocimiento 


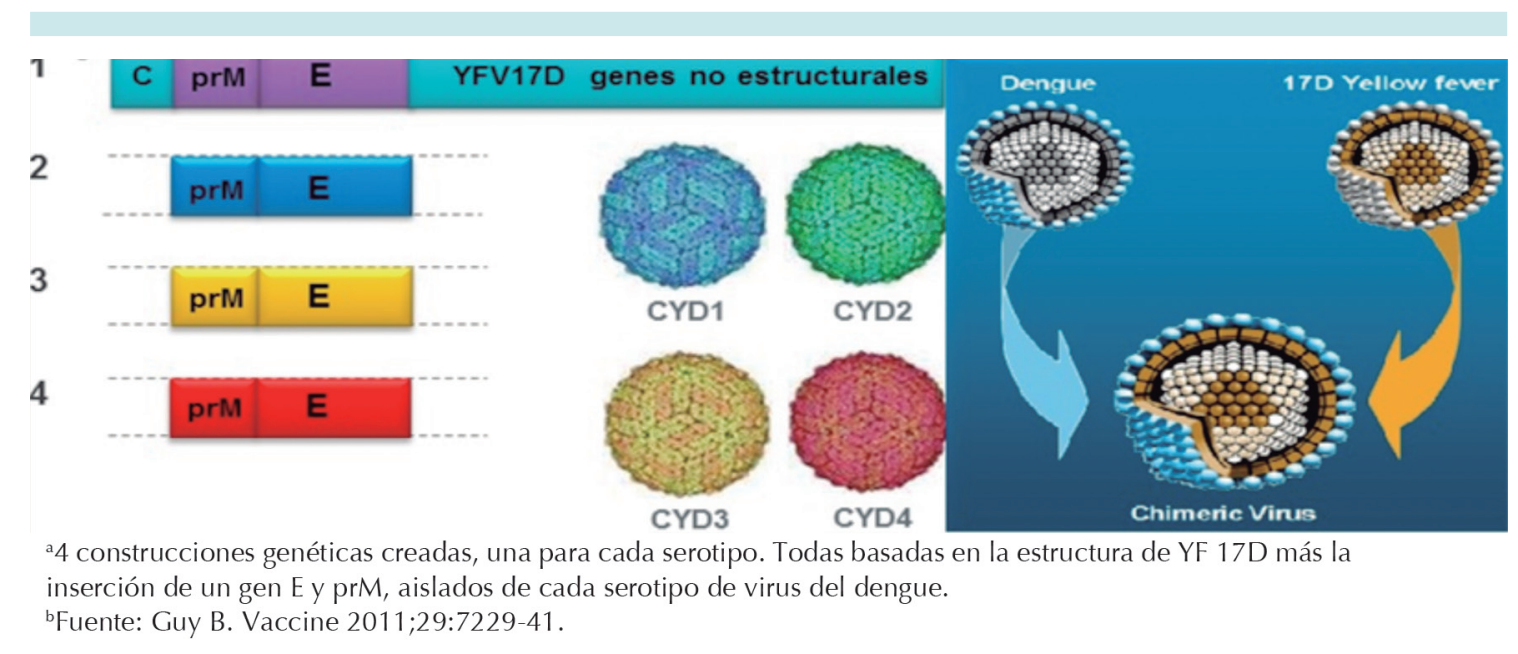

Figura 5. Estructura quimérica CYD-TDV.

celular. Su genoma tiene una alta tasa de mutación, especialmente en aminoácidos específicos en las proteínas virales: nsP1, nsP3, nsP4, E1 y E2. Sin embargo, los cambios ultraestructurales inducidos por los virus dentro de las células infectadas se mantienen altamente conservados entre las diferentes cepas de. El virus del chikungunya existe como un único serotipo que al parecer confiere inmunidad de por vida a los individuos que se recuperan de la infección. Sin embargo, hay suficiente variación para distinguir tres genotipos: el del oeste de África, el del este/ centro/ sur Africano (ECSA) y los epidémicos genotipos asiáticos. El ECSA recientemente dio lugar al linaje del océano índico, responsable de las epidemias en la India y Europa a principios del 2004..$^{15,39-43}$

\section{Patogenia}

Los mosquitos adquieren el virus a partir de un huésped virémico. Después de un periodo promedio de incubación extrínseca de diez días, el mosquito es capaz de transmitir el virus a un huésped susceptible. El virus es introducido a la piel donde se replica en los fibroblastos de la dermis y se disemina por el torrente sanguíneo hacia múltiples tejidos. En los humanos infectados, los síntomas de enfermedad aparecen generalmente después de un período de incubación intrínseca de tres a siete días (límites 1-12 días). La transmisión del virus del chikungunya además de ocurrir la picadura del vector, también puede efectuarse por vía transplacentaria, de madre virémica al recién nacido durante el parto, e incluso se sospecha que puede ocasionar abortos si ocurre en el primer trimestre del embarazo; asimismo, si ocurre en etapas más avanzadas, el bebé no adquiere inmunidad a través de la madre ni existe evidencia de transferencia en la leche materna. La replicación viral ocurre principalmente en los tejidos diana, como: músculos, articulaciones y la piel, además del hígado, bazo y meninges en neonatos y pacientes con comorbilidades. El periodo de incubación termina con la aparición súbita de fiebre, lo que coincide con la viremia, y la carga viral puede alcanzar rápidamente $10^{9}$ copias por mililitro. La replicación viral desencadena la activación de la inmunidad innata, de la cual la producción de interferón de tipo I (IFN) es el sello distintivo. La fiebre usualmente dura menos de una semana, hasta que la viremia acaba. En este momento es cuando los pacientes producen inmunidad adaptativa anti-virus del chikungunya, 
caracterizada por anticuerpos IgM anti-virus del chikungunya. Aunque el virus no es considerado neurotrópico, la evidencia reciente sugiere una afectación neurológica, lo que es más notable en neonatos, niños pequeños y ancianos infectados. La enfermedad crónica por chikungunya consiste en dolor articular persistente y recaídas, por semanas, meses o años. Esta enfermedad crónica está asociada con niveles detectables de IL-17 y elevados de IL-6, además de factor estimulador de colonias de granulocitos durante los primeros meses posinfección. La fisiopatología de la enfermedad crónica por virus del chikungunya aún está pobremente estudiada y a la fecha ningún modelo animal reproduce totalmente el síndrome crónico articular asociado. En pacientes humanos con artralgia crónica inducida por virus del chikungunya se encuentra, frecuentemente, persistencia de IgM específica del virus, que podría resultar de la continua exposición al antígeno del virus del chikungunya. Un estudio ya ha brindado evidencia de la persistencia de antígenos virales y ARN en el tejido sinovial de un paciente con artralgia crónica por 18 meses después de la infección por virus del chikungunya. La presencia de ARN tanto en casos humanos como en modelos animales plantea la cuestión del rol del ARN del virus del chikungunya en la inflamación y daño articular, ya que se ha demostrado que el ARN de doble cadena, producto de la replicación de genoma viral, es artritogénico. ${ }^{39-40,44}$

\section{Epidemiología}

Desde 1770 se han reportado epidemias de fiebre, rash y artritis semejantes a la fiebre del chikungunya. Sin embargo, el virus no se aisló de suero humano o mosquitos hasta una epidemia en Tanzania en 1952-1953. Luego de la identificación inicial del virus del chikungunya continuaron ocurriendo brotes esporádicos, pero se reportó poca actividad después de mediados de los años 80. No obstante, en 2004, un brote originado en Kenia se diseminó durante los dos años siguientes a Comoros, La Reunión y muchas otras islas del Océano Índico. Se estima que ocurrieron 500,000 casos desde la primavera del 2004 al verano del 2006 y a partir de esa fecha la enfermedad se extendió a toda Europa. Posteriormente los primeros casos de virus del chikungunya en el continente americano se registraron en diciembre del 2013 en la isla de San Martín y posteriormente se notificaron casos de transmisión autóctona en el Caribe. Los países de América con mayor número de casos confirmados por laboratorio son México en primer lugar, Brasil y Ecuador. En México se confirmó el primer caso en 2014 de una paciente con fiebre chikungunya en Jalisco, importado por asistir a un evento deportivo en el Caribe. Actualmente, a la semana epidemiológica 49, se reportan 11,394 casos confirmados de fiebre chikungunya en México. La diseminación a otros estados y países se dio rápidamente con tasas de ataque en las comunidades afectadas de entre el 38 a $63 \%$. La tasa de ataque en niños menores de 8 años es de $1.5 \%$, probablemente subestimada ya que especialmente los niños experimentan síntomas más atípicos. Asimismo, debe considerarse que entre el 3 a $38 \%$ de la población tiene infecciones asintomáticas, estos últimos contribuyen significativamente a la diseminación de la enfermedad. Existen dos vectores principales: Aedes aegypti y Aedes albopictus, sin embargo Ae. vigilax también se ha confirmado como un vector eficaz para el virus del chikungunya. Dada la amplia distribución de los primeros dos en las Américas, toda la región ha sido susceptible para la diseminación del virus. El humano es el principal reservorio durante los períodos epidémicos y en los periodos interepidémicos, diversos vertebrados han sido implicados como reservorios potenciales, incluyendo primates no humanos, roedores, aves y algunos mamíferos pequeños. ${ }^{39-40,45-7}$

Para sorpresa de algunos investigadores quienes pensaban que la reciente epidemia de virus del chikungunya fue el primer episodio en América, un artículo reciente ha manifestado que los bro- 
tes de virus del chikungunya han ocurrido al sur de los Estados Unidos desde 1827, y que muchos de los brotes de "dengue" registrados antes de la era de técnicas confirmatorias de laboratorio, representan en realidad casos mal identificados de virus del chikungunya ${ }^{48}$ (Cuadro 2).

\section{Manifestaciones clínicas}

Aunque la fiebre chikungunya rara vez pone en peligro la vida, los síntomas pueden ser incapacitantes haciendo que los pacientes no puedan ir a trabajar, generando costos muy altos. La confusión y superposición clínica con otras fiebres indiferenciadas como el dengue (que sí puede ser fatal), son preocupaciones adicionales de las regiones afectadas. Los síntomas se presentan tras un período de incubación de tres a siete días. El virus del chikungunya puede causar enfermedad aguda, subaguda y crónica. La enfermedad aguda se caracteriza por inicio súbito de fiebre alta, superior a $39^{\circ} \mathrm{C}$, y dolor articular severo o incapacitante, lo que ha sido reportado en $96.6 \%$ de los pacientes y que lo diferencia de la fiebre por dengue. Otros signos y síntomas pueden incluir cefalea, dolor difuso de espalda, mialgias, náuseas y vómitos, poliartritis, rash y conjuntivitis. La fiebre generalmente dura entre unos días y una semana. Puede ser continua o intermitente, pero una disminución de la temperatura no se asocia a empeoramiento de los síntomas. Los síntomas articulares generalmente son simétricos y ocurren con más frecuencia en manos y pies, pero también pueden afectar articulaciones más proximales. A menudo los pacientes adultos están incapacitados por el dolor, la sensibilidad, la inflamación y la rigidez; sin embargo, se ha reportado que la artralgia es más leve en los niños. El rash aparece generalmente entre dos a cinco días después del inicio de la fiebre en aproximadamente el $50 \%$ de los pacientes. Es típicamente maculopapular e incluye tronco y extremidades, aunque también puede afectar palmas, plantas y rostro. En los niños pequeños, las lesiones vesiculobulosas son las manifestaciones cutáneas más comunes y, aunque raras, se han descrito complicaciones como uveítis, iridociclitis, retinitis parálisis flácida, encefalitis, meningoencefalitis, Guillain-Barré, miocarditis, neumonía, nefritis, hepatitis y pancreatitis. Otros síntomas menos frecuentes son linfadenopatía, prurito, anormalidades digestivas y trastornos psiquiátricos, en los cuales los episodios depresivos son los más comunes. La combinación de rash, artralgia y cuenta de glóbulos blancos menor a $7,000 / \mu \mathrm{L}$ tiene una sensibilidad y especificidad del $94 \%$ y $84 \%$ respectivamente para detectar casos de fiebre chikungunya, si le añadimos un conteo plaquetario mayor a 150,000/ $\mu$ l estas 4 características nos ayudarían a diferenciar entre infecciones causadas por virus del chikungunya de aquellas por virus del dengue. Las manifestaciones hemorrágicas son raras, sólo en 1-7\% se presentan como epistaxis o gingivorragia. En contraste con las otras manifestaciones clínicas, el dolor articular puede persistir y recurrir por semanas, meses e incluso años, lo que tampoco se ve en el dengue. El dolor está ubicado usualmente en las mismas articulaciones afectadas durante la fase aguda y aunque la proporción de pacientes con síntomas crónicos disminuye con el tiempo (menos de $50 \%$ después de 5 años) el tiempo requerido para curar todos los síntomas es incierto. Las manifestaciones de laboratorio son similares a las del dengue excepto por una leucopenia y trombocitopenia menos pronunciadas. En el diagnóstico diferencial deben considerarse enfermedades infecciosas como malaria, DENF, leptospirosis, artritis posinfecciosa y artritis reumatoidea juvenil ${ }^{15,39,41,43-4,48-9}$ (Cuadro 3).

\section{Diagnóstico}

Para el diagnóstico de fiebre chikungunya se utilizan tres tipos principales de pruebas: aislamiento viral, reacción en cadena de la polimerasa con transcriptasa inversa y serología. Los métodos 
Cuadro 2. Incidencia de infecciones por virus del chikungunya en América a la semana 49 del 2015

\begin{tabular}{lccccc}
\hline Región & Casos autóctonos & Casos importados & Tasa de incidencia & Muertes & Población x 1,000 \\
Norteamérica & 11,050 & 737 & 2.3 & 0 & 486,303 \\
Centroamérica & 4,673 & 17 & 400 & 3 & 46,695 \\
Caribe latino & 1,964 & 0 & 29.9 & 3 & 37,364 \\
Andes & 8,715 & 99 & 291.4 & 71 & 139,231 \\
Cono Sur & 7,233 & 54 & 7.3 & 0 & 274,196 \\
Caribe no latino & 882 & 1 & 98 & 0 & 7,345 \\
Total & 34,507 & 908 & 64.8 & 77 & 991,134
\end{tabular}

Número de casos reportados de chikungunya en América, Organización Panamericana de la Salud, 2015.

Cuadro 3. Comparación entre las características clínicas y de laboratorio de las infecciones por virus del chikungunya y del dengue ${ }^{a}$

\begin{tabular}{lcc}
\hline $\begin{array}{l}\text { Características } \\
\text { clínicas y } \\
\text { de laboratorio }\end{array}$ & $\begin{array}{c}\text { Infección por virus } \\
\text { del chikungunya }\end{array}$ & $\begin{array}{c}\text { Infección } \\
\text { por virus del } \\
\text { dengue }\end{array}$ \\
Fiebre $>39^{\circ} \mathrm{C}$ & +++ & ++ \\
Mialgias & + & ++ \\
Artralgias & +++ & $+/-$ \\
Cefalea & ++ & ++ \\
Rash & ++ & + \\
Discrasias sanguíneas & + b & ++ \\
Shock & - & + \\
Leucopenia & ++ & +++ \\
Neutropenia & + & +++ \\
Linfopenia & +++ & +++ \\
Hematocrito elevado & - & ++ \\
Trombocitopenia & + & +++
\end{tabular}

a Frecuencia media de los síntomas a partir de estudios donde las dos enfermedades se compararon directamente entre pacientes que solicitaron atención sanitaria: $+++=70-100 \%$; $++=40-69 \% ;+=10-39 \%,+/-<10 \% ;-=0 \%$.

${ }^{\mathrm{b}}$ Generalmente retroorbital.

Tabla modificada a partir de Staples, et al.

moleculares y virológicos son más sensibles durante las etapas tempranas de la enfermedad (2-5 días después de la fiebre) cuando aún no se detectan anticuerpos. Sin embargo, en las etapas tardías de la infección, la sensibilidad de estos métodos se reduce debido al inicio de la respuesta inmunológica y reducción de la carga viral. En este punto la IgM ELISA es una prueba más sensible. No existe aún un ensayo comercial basado en la detección de antígenos para virus del chikungunya, y las descritas hasta ahora en la literatura no han establecido bien sus características de rendimiento. Otras técnicas de diagnóstico podrían estar disponibles en un futuro para diagnóstico simultáneo de dengue y chikungunya. Una técnica que está alcanzando popularidad es el inmunoensayo basado en microesferas. Esta tecnología se basa en detección por citometría de flujo de un antígeno o anticuerpo adjunto a microesferas. Esta es una prueba más rápida que la MAC-ELISA y tiene el potencial para desarrollarse en multiplex. Similarmente, la tecnología de microarray, que se enfoca en la detección de fragmentos de ácidos nucleicos pertenecientes a distintos patógenos, es útil para analizar una muestra de un paciente con síntomas infecciosos con un amplio diagnóstico diferencial. Finalmente, la espectrometría de masa puede ser aplicada a este campo de diagnóstico, probando su utilidad en determinar los genotipos virales durante un brote..$^{39,43}$

\section{Tratamiento}

Actualmente no existe un fármaco antiviral específico para fiebre chikungunya. El tratamiento principal en la actualidad es sintomático con antipiréticos, analgésicos e hidratación luego de excluir enfermedades más graves como la malaria, dengue e infecciones bacterianas. El tratamiento sintomático y de soporte incluye reposo y el uso de acetaminofén para alivio de la fiebre, e ibuprofeno, naproxeno o algún otro agente antiinflamatorio no esteroideo para aliviar el componente artrítico de la enfermedad. 
No se aconseja el uso de aspirina debido al riesgo de sangrado en un número reducido de pacientes y el riesgo de desarrollar síndrome de Reye en niños menores de 12 años de edad. En pacientes con dolor articular grave que no se alivia con antiinflamatorios no esteroideos se pueden utilizar analgésicos narcóticos (por ej., morfina) o corticoesteroides a corto plazo después de hacer una evaluación riesgo-beneficio de estos tratamientos. Se debe aconsejar a los pacientes beber grandes cantidades de líquidos para reponer el líquido perdido en sudoración, vómito y otras pérdidas insensibles. En algunos pacientes el periodo de convalecencia puede ser prolongado y el dolor articular persistente puede requerir tratamiento analgésico, incluyendo terapia antiinflamatoria prolongada. Existen pocos estudios de tratamiento con fosfato de cloroquina, con resultados variables. La artritis periférica incapacitante puede responder a inyecciones intra-articulares de corticoesteroides o terapia tópica con antiinflamatorios no esteroideos. La hidroxicloroquina combinada con corticoesteroides ha tenido éxito al tratar las manifestaciones reumáticas crónicas. El metotrexate y la sulfasalazina (solos o en combinación) también han sido útiles para tratar la artritis crónica por virus del chikungunya. Se recomienda vigilar estrechamente a los pacientes durante tres meses para estimar la necesidad de posible tratamiento inmunodepresor. Además de la farmacoterapia los casos de artralgias prolongadas y rigidez articular pueden beneficiarse con un programa progresivo de fisioterapia. El movimiento y el ejercicio moderado tienden a mejorar la rigidez matinal y el dolor, pero el ejercicio intenso puede exacerbar los síntomas. ${ }^{15,39,51-2}$

Otras terapias para tratar la infección por virus del chikungunya están en desarrollo y han demostrado cierta eficacia en modelos animales. Una de ellas es el uso de un intrón Grupo I de doble efecto que ha demostrado suprimir efectivamente la replicación tanto de chikungunya como de dengue, proporcionando así una te- rapia antiviral prometedora para la supresión transgénica de múltiples arbovirus. Otra terapia prometedora es la inmunización pasiva con anticuerpos monoclonales IgM dirigidos contra la proteína E1 o E2 del virus del chikungunya. Esto podría constituir una intervención médica eficaz para pacientes expuestos a chikungunya con riesgo de enfermedad severa. Esta profilaxis podría incluso recomendarse a neonatos nacidos de madres virémicas, y que están en riesgo de desarrollo de infección severa. ${ }^{44,47,53}$

Similar al dengue, la fiebre chikungunya se encuentra en el mismo escenario con sólo dos vacunas candidatas, las cuales recientemente se aprobaron para entrar a ensayos clínicos de fase II. Una versión con partículas virales similares Ilamada VRC 311 y una vacuna recombinante con virus de sarampión vivos atenuados. VRC 311 fue altamente inmunogénica y los anticuerpos neutralizantes aún se detectaban en $85 \%$ de los vacunados 12 meses después, $8 \%$ tuvieron efectos secundarios bien tolerados como artralgia transitoria. La vacuna basada en virus de sarampión originó seroconversión en $100 \%$ de los participantes después de una segunda vacunación, y tuvo un perfil de seguridad adecuado. Aunque estas vacunas contra el chikungunya estén ya en ensayos clínicos avanzados aún falta mucho para que se les otorgue licencia y puedan comercializarse. ${ }^{54-5}$

\section{ZIKA}

\section{Generalidades}

La infección por virus zika es una enfermedad emergente causada por el virus del mismo nombre, que es transmitido a través de la picadura de mosquitos del género Aedes tales como Ae. aegypti, Ae. albopictus, Ae. polynesiensis y Ae. hensilli. Es un arbovirus de la familia Flaviviridae que contiene una sola cadena de ARN. Se han identificado dos linajes principales: el asiático y el africano. Su transmisión es tanto 
selvática como urbana y se sugiere que pueda tener reservorios primates no humanos. Algunos autores indican haber encontrado anticuerpos anti-zika en varios animales como orangutanes, cebras, elefantes y roedores. ${ }^{15-56}$

\section{Epidemiología}

La enfermedad fue identificada en 1947 en un mono Rhesus utilizado como centinela en la supervisión de fiebre amarilla en el bosque de Zika, Uganda. En 1968 fue aislado por primera vez en humanos en Nigeria y de 1951 a 1981 se informó de casos en 13 países de África como de Asia. Dada la ocurrencia de brotes de zika en Polinesia, en 2013 el gobierno chileno inició la vigilancia en las Islas del Pacífico Sur e identificó en 2014 el primer caso autóctono de infección por virus del chikungunya en América, en la isla de Pascua. Durante el 2015, Brasil informó la transmisión autóctona de virus zika en 18 estados y tres defunciones asociadas. También se ha notificado en Colombia, El Salvador, Guatemala, Paraguay, Suriname y Venezuela. En México durante el mes de noviembre del 2015 se identificaron dos casos autóctonos de infección por virus zika, el primero en Monterrey y el segundo en Chiapas, ambos caracterizados por fiebre, exantema y conjuntivitis no purulenta. Ninguno con antecedentes de viaje a zonas con transmisión ni contacto con casos confirmados a virus zika. Actualmente, al final de la semana epidemiológica 6 del 2016 se cuenta con 91 casos confirmados y 15 acumulados del $2015 . .^{57-9}$

\section{Manifestaciones clínicas y de laboratorio}

Se estima que cuatro de cada cinco pacientes son asintomáticos. Los síntomas aparecen entre 3 a 12 días después de la picadura del mosquito y los más comunes son fiebre leve, exantema, conjuntivitis no purulenta y artritis, principalmente en pies y manos. Otros síntomas incluyen mialgias, artralgias, cefalea, dolor retro-ocular, edema de miembros inferiores, vértigo, dolor abdominal y vómito. La enfermedad generalmente es leve y autolimitada con duración de dos a siete días. Sin embargo, se han descrito complicaciones neurológicas y autoinmunitarias, así como malformaciones congénitas (microcefalia). Es infrecuente que la infección por zika cause la muerte; sin embargo, se han descrito tres defunciones durante la reciente epidemia de Brasil. Todos los pacientes presentan exantema y la mayoría prurito. La fiebre ocurre en el $75 \%$ de los pacientes, pero sólo en $25 \%$ es mayor de $39^{\circ} \mathrm{C}$ de uno hasta ocho días. Ocurre linfadenopatía submandibular o cervical en $35.5 \%$. Al contrario de los síndromes causados por chikungunya y dengue, no son comunes la hemorragia, la leucopenia, la trombocitopenia ni la hepatomegalia. En cambio es más frecuente el edema de extremidades y la conjuntivitis no purulenta, lo que no ocurre en fiebre chikungunya ni en dengue..$^{56,58-61}$

\section{Diagnóstico}

El diagnóstico de zika se basa mayormente en la detección de ARN en muestras de sangre: por reacción en cadena de la polimerasa con transcriptasa inversa o aislamiento viral en muestras recolectadas a menos de cinco días de iniciados de los síntomas. La técnica de amplificación "pan flavivirus" con secuenciación también puede utilizarse como alternativa. El periodo virémico en humanos es corto, de tres a cinco días luego de iniciados los síntomas. La viruria puede durar más y la detección de ARN viral por reacción en cadena de la polimerasa con transcriptasa inversa en orina puede ser un método alternativo de detección de material genético ya no presente en el suero. Las pruebas serológicas también son ampliamente usadas. Sin embargo, la frecuencia de reacciones cruzadas con otros flavivirus puede hacer difícil el diagnóstico. Además, en la fase temprana de la infección, los niveles de IgM e IgG pueden ser muy bajos 
dificultando la confirmación del diagnóstico. Actualmente no existen equipos comerciales para la detectar anticuerpos relacionados al virus zika. ${ }^{56}$

\section{Tratamiento}

No existe tratamiento específico ni vacuna. El tratamiento es sintomático, combinando acetaminofén y antihistamínicos. Se tiene que vigilar estrechamente a los pacientes por el riesgo elevado de síndromes neurológicos como Guillain-Barré, con especial atención a las embarazadas ya que el virus zika ha sido estrechamente asociado a malformaciones fetales del tubo neural y cráneo-faciales. ${ }^{56,58}$

\section{Asociación con microcefalia y afectación del sistema nervioso}

El virus zika es endémico de África y Asia y se ha documentado una seroprevalencia de más del $30 \%$ en algunos países africanos. Desde 1960 se reportan casos raros y esporádicos, pero la primer epidemia documentada fue en el 2007 en Micronesia. La forma africana replica varios de los síntomas asociados a arbovirus y el brote en Micronesia presentó las mismas características, sin embargo, la observación de síndrome de Guillain-Barré en los casos de zika en Polinesia, en 2013, representó un incremento en la potencial severidad clínica de la enfermedad y de su afectación al sistema nervioso, por lo tanto, su denominación como el "primo más leve del dengue" no es adecuada debido a la posibilidad de síntomas más severos. En los ratones el virus zika es altamente neurotrópico; el virus no ha sido aislado de otros tejidos aparte del cerebro y la patología muestra degeneración neuronal, infiltración celular y ablandamiento de los cerebros infectados de ratones jóvenes. Brasil ha sido el país más fuertemente azotado por las complicaciones de zika con cerca de 4,000 bebés nacidos con microcefalia desde octubre del año pasado. En 2014, la Polinesia
Francesa reportó también un pico en el número de bebés nacidos con esta condición. El reciente incremento en la incidencia de microcefalia en Brasil, en la misma región en que se presentaron los brotes de virus zika, ha hecho que se sospeche una fuerte asociación entre ellos, ya que se ha aislado ya al virus en el líquido amniótico de mujeres embarazadas cuyos fetos mostraron reducción de la circunferencia craneal y otras anomalías cerebrales, y se ha detectado ARN del virus en tejido placentario y tejido cerebral en infantes con microcefalia y de pérdidas fetales de mujeres infectadas durante el embarazo. Estos graves efectos de la infección de virus zika en los fetos, no reportada previamente, no son tan sorprendentes considerando la transmisión perinatal de varias mujeres en Polinesia y el fuerte neurotropismo del virus. Aparte se ha documentado ya la transmisión sexual, sanguínea, por exposición en laboratorio y el virus zika ha sido aislado del semen de varios pacientes, el primero durante el brote en Polinesia de un paciente que buscó tratamiento por hematospermia. La transmisión perinatal de arbovirus ha sido reportada para dengue, chikungunya, virus del Oeste del Nilo y virus de la fiebre amarilla. Transmisión a través de la leche materna ha sido documentada en el caso de dengue y virus del Oeste del Nilo. Graves consecuencias de la transmisión materno-fetal han sido reportadas, notablemente para virus del chikungunya (encefalopatía y fiebre hemorrágica) y virus del dengue (parto pretérmino, muerte fetal, bajo peso al nacer, anomalías fetales, prematuridad y sufrimiento fetal agudo). Dentro de las anomalías ultrasonográficas de los fetos de madres infectadas con virus zika se observó microcefalia con calcificaciones del cerebro fetal y de la placenta. Las autopsias revelaron microcefalia con agiria casi completa, hidrocefalia y calcificaciones distróficas multifocales en la corteza y sustancia blanca subcortical con reemplazo cortical asociado e inflamación focal leve. Aparte de las anomalías del sistema nervioso de los fetos se encuentran hallazgos 
oculares como pigmentación focal retiniana y atrofia coriorretiniana, anormalidades del nervio óptico, coloboma del iris bilateral y subluxación del cristalino. Las infecciones causantes de microcefalia y lesiones retinianas típicamente ocurren durante el primero o segundo trimestre del embarazo. Después de secuenciar completamente el genoma del virus zika brasileño, el análisis filogenético demostró que comparte más de $97 \%$ de su genoma con los linajes aislados durante el brote en Polinesia, descartando la posibilidad de eventos recombinantes del virus zika con otros flavivirus y de que el virus zika brasileño sea una cepa recombinante. Se ha observado que las cepas virales de la Isla de Pascua están más cercanamente relacionadas con aquellas encontradas en Polinesia (98.8-99.9\%). Por otro lado exhibieron una coincidencia de 98.1 a $98.3 \%$ en la secuencia a las cepas de Cambodia en 2010 y Micronesia en 2007. Las variaciones en la secuencia de nucleótidos del gen NS5, en algunas cepas, están localizadas en el tercer nucleótido del codón, resultando en la conservación de aminoácidos. A pesar de no haber encontrado evidencia de eventos recombinantes en el genoma del virus zika se sospecha la ocurrencia de cambios genéticos responsables de cambios fenotípicos y ha sido reportada en otros virus similares. Incluso si toda esta información sugiere una fuerte asociación entre virus zika y microcefalia, aún no se establece una relación de causalidad. El siguiente paso será hacer estudios de casos y controles para estimar el riesgo potencial de microcefalia tras la infección por zika durante el embarazo, además de otras complicaciones fetales y neonatales, así como pronósticos a largo plazo para neonatos sintomáticos y asintomáticos infectados. La amniocentesis para detectar infección por virus zika está ampliamente recomendada a pesar de la poca información acerca del valor predictivo asociado a detección de zika en el líquido amniótico en embarazadas, especialmente en fetos asintomáticos. Así como sucede con otros virus teratogénicos, parece improbable que 100\% de los fetos infectados desarrollarán síntomas. El valor predictivo positivo para la detección del virus zika en el líquido amniótico debe ser urgentemente determinado antes de que sean hechas amniocentesis potencialmente innecesarias. Es difícil explicar porque no se habían reportados casos fetales de infección por virus zika hasta ahora, pero esto podría ser debido al sub-reporte de los casos, posible inmunidad en áreas endémicas o la rareza de la enfermedad hasta ahora. Ya que se han documentado algunos cambios genómicos, la posibilidad de una nueva y más virulenta cepa debe ser considerada, así como una mejor adaptación a la transmisión por Ae. aegypti, ya que en el continente africano se ha aislado principalmente en otra especie de $A e$ des. Hasta que no sean diagnosticados más casos y haya más pruebas histopatológicas la posibilidad de otras etiologías no puede descartarse. $\mathrm{Ha}$ surgido, recientemente, la preocupación de que la elevada frecuencia de microcefalia asociada con zika, en Brasil, sea consecuencia de una mutación del virus promovida por los mosquitos transgénicos OX513A que se producen en Brasil desde el 2011 y, que de alguna manera, se pusieron en contacto con suficiente tetraciclina (la cual produce un switch genético que les permite sobrevivir) y ahora transmiten el virus con mucho más eficiencia. Sin embargo, se ha encontrado que los niveles bajos de tetraciclina y sus análogos encontrados en el medio ambiente no impactan en la eficacia ni seguridad de OX513A para controlar Ae. aegypti e, incluso si alguna hembra adulta adquiere suficiente cantidad de tetraciclina en su dieta, se observó que esto no es capaz de incrementar la supervivencia de la progenie. Todo lo anterior haciendo improbable la eficaz transmisión de arbovirus. ${ }^{56,62-78}$

\section{VIRUS MAYARO}

El virus mayaro, el agente etiológico de la fiebre mayaro, pertenece al grupo de alfavirus artritogénicos como el virus del chikungunya. El virus mayaro fue aislado por primera vez en 
1954 en Trinidad y, desde entonces, ha sido aislado en varios países sudamericanos. Es un virus zoonótico transmitido por tres mosquitos del género Haemagogus; sin embargo, hay datos que sugieren que Ae. aegypti puede servir como un vector competente, por lo tanto, el potencial para que el virus mayaro emerja como un patógeno global no puede ser subestimarse. El virus es exclusivo de América y sus hospederos principales son las aves, el humano actúa como hospedero incidental, así como algunos otros mamíferos. $^{79,80}$

Clínicamente la fiebre mayaro se caracteriza por síntomas inespecíficos como fiebre alta, rash, mialgia, dolor de cabeza y artralgia. El 54\% de los pacientes infectados con virus mayaro desarrollan artralgia persistente de las grandes articulaciones. ${ }^{79}$

En México se han descrito pocos casos; sin embargo, en 2006 se estudiaron 35 casos de pacientes con enfermedad febril hemorrágica en una institución pública. De estos 35 casos, dos fueron positivos para mayaro, ambos con sangrado por trombocitopenia e ictericia. Uno de ellos con datos de encefalopatía que lo llevó a la muerte después de 30 días de estancia intrahospitalaria. ${ }^{3}$

Innovaciones en control de vectores

Las infecciones por dengue, chikungunya y zika seguirán ocurriendo anualmente si no se controla apropiadamente a los vectores. Las nuevas recomendaciones son aquellas que los servicios de control de vectores pueden implementar a corto plazo usando sus recursos existentes como: 1) rotación y mosaicos de insecticidas para lograr un manejo adecuado de las resistencias, 2) empoderar a las comunidades para la participación en actividades rutinarias de control y 3 ) eficacia y efectividad mejoradas de los programas de control de vectores con requerimientos financie- ros y de personal mínimos. Los insecticidas más usados en México son los piretroides, temefos, spinosad, malatión y el Bacillus thuringiensis var. Israelensis. ${ }^{54,81}$

La falla de los actuales métodos ha Ilevado al desarrollo de nuevas estrategias como las técnicas de insectos estériles (SIT, por sus siglas en inglés) que se han incrementado en los últimos años y la más importante es la de los mosquitos irradiados y transgénicos, ambas técnicas basadas en la liberación de machos estériles que copulan con hembras salvajes, produciendo descendencia infértil. Además de éstas se encuentran las técnicas de insectos incompatibles (IIT) que usa la bacteria Wolbachia para producir incompatibilidad citoplasmática en mosquitos Aedes. Este mecanismo produce la muerte de la progenie cuando los machos infectados con Wolbachia se aparean con hembras no infectadas. Además, esta técnica disminuye la habilidad del vector para transmitir dengue y chikungunya, suprimiéndolos. ${ }^{54}$

\section{CONCLUSIONES}

Por la situación geográfica de América Latina y el intercambio comercial reflejado en los fenómenos de migración con otros países, así como la presencia de mosquitos altamente capacitados como vectores, es inevitable la emergencia, re-emergencia y diseminación de arbovirus en nuestro continente, por lo que a pesar del desarrollo de nuevas técnicas, tanto de diagnóstico como de tratamiento, así como de vacunas en el caso de chikungunya y dengue, el pilar del control y prevención de arbovirus debe centrarse en el control de los vectores, ya que no se tiene conocimiento de cuándo emergerá un nuevo arbovirus o una nueva mutación o serotipo de los ya existentes y que destruyan el esfuerzo destinado en el manejo de estas enfermedades. La prevención se centra en disminuir el número de mosquitos reduciendo el número de sitios para 
depósito de huevos (macetas, Ilantas, reservas de agua, entre otras) secándolas, insolándolas o tratándolas con insecticidas. La protección individual incluye usar ropa larga y de colores brillantes, usar repelentes de mosquitos, además de mallas para las camas, puertas y ventanas y así evitar la picadura de mosquitos. ${ }^{40,56}$

\section{REFERENCIAS}

1. World Health Organization: Arbovirus and human disease. WHO Technical Report Series. (Geneva).1967;369:1-84.

2. Division of Vector-Borne Diseases: Vector-Borne threats and what we do about them. Centers for Disease Control and Prevention. (Atlanta) 2014. [Última actualización: 31 de julio del 2014] [ Acceso: 11 de noviembre del 2015] Disponible en: http://www.cdc.gov/ncezid/dvbd/about. htm

3. Navarrete-Espinosa J, Gómez-Dantés H: Arbovirus causales de fiebre hemorrágico en pacientes del Instituto Mexicano del Seguro Social. Rev Med Inst Mex Seguro Soc. 2006;44 (4):347-353

4. Normile D. Surprising new dengue virus throws a spanner in disease control efforts. Science. 2013;342:415.

5. van den Hurk AF, Hall-Mendelin S, Pyke AT: Vector competence of Australian mosquitoes for chikungunya virus. Vector-Borne and Zoonotic Diseases. June 2010, 10(5): 489-495. doi:10.1089/vbz.2009.0106.

6. Fajardo-Dolci G, Melijem-Moctezuma J, Vicente-González $E$, et al. El dengue en México. Rev Med Inst Mex Seguro Soc. 2012;50 (6):631-39.

7. Thirión-Icaza J: El mosquito Aedes aegypti y el dengue en México [Monografía de Internet]. México: Bayer Environmental Science. 2010. [Acceso 15 de noviembre del 2015]. Disponible en: http://www.slipe.org/pdf/ libro_jthpdf.pdf

8. Villegas-Trejo A, Che-Mendoza A, González-Fernández M: Control enfocado de Aedes aegypti en localidades de alto riesgo de transmisión de Dengue en Morelos, México. Salud Pública Méx. 2011;53(2):141-51.

9. Kuhn RJ, Zhang W, Rossmann MG, et al. Structure of dengue virus: implications for flavivirus organization, maturation, and fusion. Cell. 2002; 108: 717-725. doi: 10.1016/s00928674(02)00660-8.

10. Villar L, Dayan GH, Arredondo-García JL, et al: Efficacy of a tetravalent dengue vaccine in children in Latin America. N Engl J Med. 2015; 372:113-23. DOI: 10.1056/NEJMoa1411037

11. Holmes EC. Molecular epidemiology and evolution of emerging infectious diseases. Brit Mel Bull.1998;54:533-543.

12. Da Silva Voorham J.M. A possible fifth dengue virus serotype. Ned. Tijdschr. Geneeskd.2014;158:A7946.
13. Vasilakis N, Durbin AP, da Rosa AP: Antigenic relationships between sylvatic and endemic dengue viruses. Am J Trop Hyg. 2008;79(1):128-32.

14. AngelRMd, Valle JR-d. Dengue Vaccines: Strongly Sought but Not a Reality Just Yet. PLoS Pathog. 2013;9(10): e1003551.

15. Uribarren-Berrueta T: Dengue, fiebre Chikungunya y otros arbovirus. Recursos en virología. México (2015). Acceso: 15 de noviembre del 2015. Disponible en: http://www.facmed. unam.mx/deptos/microbiologia/virologia/dengue.html

16. Chareonsirisuthigul T, Kalayanarooj $S$, Ubol S. Dengue virus (DENV) antibody-dependent enchancement of infections upregulates the production of anti-inflammatory cytokines, but suppresses anti-DENV free-radical and proinflammatory cytokine production, in THP-1 cells. Journal of General Virology (2007), 88, 365-375.

17. Guy B, Jackson N: Dengue vaccine: hypotheses to understand CYD-TDV-induced protection. Nature Reviews. France (2015). doi:10.1038/nrmicro.2015.2

18. Pan American Heatlh Organization: Number of Reported Cases of Dengue and Severe Dengue in the Americas, by Country-December 1, 2015 (EW 45). Annual Cases Reported of Dengue (Atlanta) 2015. Accesado: 3 de Diciembre del 2015. Disponible en: http://www.paho.org/hq/index. php?option $=$ com_topics\&view $=$ rdmore \&cid $=6290 \&$ Itemi $\mathrm{d}=40734$ \&lang=en

19. Dirección General de Epidemiología: Panorama Epidemiológico de Fiebre por Dengue y Fiebre Hemorrágica por Dengue. Secretaría de Salud (México) 2015. Acceso: el 3 de diciembre del 2015. Disponible en: http://www.epidemiologia.salud. gob.mx/dgae/panodengue/intd_dengue.html

20. Zambrano B, San Martin JL: Epidemiology of Dengue in Latin America. Journal of the Pediatric Infectious Diseases Society. 2015; Vol.3, No. 3, pp. 181-2

21. Picollo-Oliveira JF, Burdmann EA: Dengue-associated acute kidney injury. Clinical Kidney Journal. 2015; vol. 8, no. 6, 681-685.

22. de Souza LJ, Pessanha LB, Mansur LC, et al: Comparison of clinical and laboratory characteristics between children and adults with dengue. Braz J Infect Dis. 2013; 17 (1): 27-31.

23. Kittigul L, Pitakarnjanakul P, Sujirarat $D$, et al. The differences of clinical manifestations and laboratory findings in children and adults with dengue virus infection. J Clin Virol, 2007;39:76-81.

24. Libraty DH, Wang P, Guo Z, et al: The pattern of adipose tissue accumulation during early infancy provides an environment for the development of dengue hemorrhagic fever. PLoS NegI Trop Dis. 2015; 9(12): e0004267. doi:10.1371/ journal.pntd.0004267

25. Aggarwal A, Kumar P, Faridi MM: Neurological manifestation as presenting feature of dengue infection. J Pediatr Neurosci, 2015; 10 (1): 76-7.

26. Babaliche P, DOshi D: Catching Dengue Early: Clinical Features and Laboratory Markers of Dengue Virus Infection. J Assoc Physicians( India). 2015; 63(5): 38-41. 
27. Unnikrishnan R, Faizal BP, Vijayakumar P: Clinical and laboratory profile of dengue in the elderly. J Family Med Prim Care. 2015; 4(3): 369-72.

28. Parkash O, Shueb RH: Diagnosis of dengue infection using conventional and biosensor based techniques. Viruses. 2015; 7(10): 5410-27.

29. Simmons CP, McPherson K, Van Vinh Chau N, et al: Recent advances in dengue pathogenesis and clinical management. Vaccine. 2015; 33(50): 7061-8.

30. Wongsa A: Fluid and hemodynamic management in severe dengue. Southeast Asian J Trop Med Public Health. 2015; 46 Suppl 1: 123-7

31. Medeiros DN, Ferrani JF, Delgado AF, et al: Colloids for the initial management of severe sepsis and septic shock in pediatric patients: a systematic review. Pediatr Emerg Care. 2015; 31(11): 11-6.

32. Villareal VA, Rodgers MA, Costello DA, et al: Targeting host lipid synthesis and metabolism to inhibit dengue and hepatitis C viruses. Antiviral Res. 2015; 124: 110-21.

33. Whitehorn J, Nquyen CV, Khanh LP, et al: Lovastatin for the treatmet of adult patients with dengue: a randomised, double-blind, placebo-controlled trial. Clin Infect Dis. 2015. pii: civ949. [Epub ahead of print]

34. Rattanaburee $T$, Junking $M$, Panya $A$, et al: Inhibition of dengue virus production and cytokine/chemokine expression by ribavirin and compound A. Antiviral Res. 2015; 124:83-92.

35. Choy MM, Zhang SL, Costa VV, et al: Proteasome Inhibition Suppresses Dengue Virus Egress in Antibody Dependent Infection. PLoS Negl Trop Dis. 2015; 9(11): e0004058. doi:10.1371/journal.pntd.0004058

36. Zhang F, Kramer CV: Corticosteroids for dengue infection. Cochrane Database Syst Rev. 2014; 1;7:CD003488. doi: 10.1002/14651858.CD003488.pub3.

37. Kurukularatne $C$, Dimatatac F, Teo DL, et al: When less is more: can we abandon prophylactic platelet transfusion in dengue fever? Ann Acad Med Singapore. 2011; 40:539-45.

38. COFEPRIS: México aprueba la primera vacuna contra el virus del dengue a nivel mundial. Secretaría de Salud (México) 2015. Acceso: 11 de diciembre del 2015. Disponible en: http://www.cofepris.gob.mx/Documents/NotasPrincipales/09122015.pdf

39. Organización Panamericana de la Salud: Preparación y respuesta ante la eventual introducción del virus chikungunya en las Américas. Washington, D.C.2011; 1: 1-148.

40. Martínez-Sánchez A, Martínez-Ramos EB, Chávez-Angeles MG: Panorama situacional de México ante la pandemia del virus chikunguña. Rev Med Inst Mex Seguro Soc. 2015; 53(2): 200-5.

41. Sahadeo N, Mohammed H, Allicock OM, et al: Molecular characterisation of chikungunya virus infections in Trinidad and comparison of clinical and laboratory features with dengue and other acute febrile cases. PLoS NegI Trop Dis. 2015; 9(11): doi: 10.1371/journal.pntd.0004199. eCollection 2015
42. Caglioti C, Lalle E, Castilletti C: Chikungunya virus infection: an overview. New Microbiologica. 2013; 36(3): 211-27.

43. Markedian SK, Roberts AL: Diagnostic options and challengues for dengue and chikungunya viruses. BioMed Research International. 2015; vol. 2015, Article ID 834371, 8 pages. doi:10.1155/2015/834371

44. Courderc T, Lecuit M: Chikungunya virus pathogenesis: From bedside to bench. Antiviral Res. 2015; 121: 120-31

45. Pan American Heatlh Organization: Number of Reported Cases of Chikungunya in the Americas, by Country - December 11, 2015 (EW 49). Annual Cases Reported of Chikungunya (Atlanta) 2015. Accesado: 15 de Diciembre del 2015. Disponible en:http://www.paho.org/hq/index.php?option=com docman\&task=doc_download\&ltemid=\&gid=32576\&lang=en

46. Balmaseda A, Gordon A, Gresh L: Clinical attack rate of chikungunya in a cohort of Nicaraguan children. Am J Trop Med Hyg. 2015; doi: 10.4269/ajtmh.15-0413

47. Carter JR, Taylor S, Fraser TS: Supression of the arboviruses dengue and chikungunya using a dual-acting group-l intron coupled with conditional expression of the Bax C-terminal domain. PLoS ONE. 2015; 10(11): e0139899. doi:10.1371/ journal.pone.0139899

48. Halstead SB: A re-examination of the history of etiologic confusion between dengue and chikungunya. PLoS Negl Trop Dis. 2015; 9(11): e0004101. doi:10.1371/journal. pntd.0004101

49. Bhatia MS, Gauam P, Jhanjee A: Psychiatric morbidity in patients with chikungunya fever: first report from India. J Clin Diagn Res. 2015; 9(19: VC01-VC03.

50. Staples JE, Breiman RF, Powers AM: Chikungunya fever: an epidemiological review of a re-emerging infectious disease. Clin Infect Dis. 2009; 49(6): 942-8

51. Ribéra A, Degasne I, Jaffar Bandjee MC, et al: Chronic rheumatic manifestations following chikungunya virus infection: clinical description and therapeutic considerations. Med Trop (Mars). 2012; 72 Spec No:83-5.

52. Arroyo-Ávila M, Vilá LM: Rheumatic manifestations in patients with chikungunya infection. P R Health Sci J. 2015;34(2):71-7.

53. Lam $\mathrm{s}$, Nyo $\mathrm{M}$, Phuektes $\mathrm{P}:$ A potent neutralizing IgM mAb targeting the N218 epitope on E2 protein protects against chikungunya virus pathogenesis. MAbs. 2015;7(6):1178-94.

54. Fernández-Salas I, Danis-Lozano R, Casas-Martínez M: Historical inability to control Aedesaegipty as a main contributor of fast dispersal of chikungunya outbreaks in Latin America. Antiviral Research. 2015;124:30-42.

55. Schwameis M, Buchtele N, Wadowski PP: Chikungunya vaccines in development. Hum Vaccin Immunother. 2015. 10:0. [Epub ahead of print]

56. Ioos S, Mallet HP, LeparcGoffart I, et al: Current Zika virus epidemiology and recent epidemics. Médecine et Maladies Infectieuses. 2014;44(11):302-7.

57. Comité Nacional para la Vigilancia Epidemiológica: Situación epidemiológica de infección por virus Zika en 
América. Secretaría de Salud. 2015. [Acceso: 15 de diciembre del 2015]. Disponible en: http://www.epidemiologia.salud.gob.mx/doctos/avisos/2015/zika/Aviso\%20 Epidemiol\%C3\%B3gico-ZIKA\%20VIRUS221015.pdf

58. Comité Nacional para la Vigilancia Epidemiológica: Infección por virus Zika, síndrome neurológico y anomalías congénitas. Secretaría de Salud. 2015. [Acceso: 15 de diciembre del 2015]. Disponible en: http://www. epidemiologia.salud.gob.mx/doctos/avisos/2015/zika/ Aviso_ZIKA_SX_NEUROLOGICO_101215.pdf

59. Dirección General de Epidemiología: Boletín Epidemiológico. Secretaría de Salud. 2016; 6(33): 35. [Acceso: 24 de febrero del 2016]. Disponible en: http://www.epidemiologia.salud.gob.mx/dgae/boletin/intd_boletin.html

60. Cardoso CW, Paploski IAD, Kikuti Mariana, et al: Outbreak of exanthematous illness associated with Zika, Chikungunya and Dengue viruses, Salvador, Brazil. Emerg Infect Dis. 2015; 21(12): 2274-6

61. Zanluca C, Campos-Andrade de Melo V, Pamplona-Mosimann AL, et al: First report of autochthonous transmission of Zika virus in Brazil. Mem Inst Oswaldo Cruz. 2015; 110(4):569-72.

62. Gatherer D, Kohl A: Zika virus: a previously slow pandemic spreads rapidly through the Americas. Journal of General Virology. 2016; 97: 269-73.

63. Brisola-Marcondes C, Freire de Melo-Ximenes MF: Zika virus in Brazil and the danger of infestation by Aedes (Stegomyia) mosquitoes. Rev Soc Bras Med Trop. 2015; Epub ahead of print: http://dx.doi.org/10.1590/00378682-0220-2015.

64. Besnard $\mathrm{M}$, Lastère $\mathrm{S}$, Teissier $\mathrm{A}$, et al: Evidence of perinatal transmission of Zika virus, French Polynesia, December 2013 and February 2014. Euro Surveill. 2014;19(13).

65. Musso D, Roche C, Robin E, et al: Potential sexual transmission of Zika virus. Emerg Infect Dis. 2015; 21(2): 359-61.

66. Henry R: Etymologia: Zika virus. Emerg Infect Dis. 2014; 20(6): 1090

67. Tognarelli J, Ulloa S, Villagra E, et al: A report on the outbreak of Zika virus on Easter Island, South Pacific, 2014. Archives of Virology. 2016; 161(3): 665-8.

68. Hennessey M, Fischer M, Staples JE: Zika virus spreads to new areas-region of the Americas, May 2015-January 2016. Morb Mortal Wkly Rep. 2016; 65(3): 55-8.

69. Gulland A: WHO urges countries in dengue belt to look out for Zika. BMJ. 2016;352:595.

70. Martines RB, Bhatnagar J, Keating MK, et al: Notes from the field: Evidence of Zika virus infection in brain and placental tissues from two congenitally infected newborns and two fetal losses. Morb Mortal Wkly Rep. 2016; 65: 159-60.

71. Mlakar J, Korva M, Tul N, et al: Zika virus associated with microcephaly. N Engl J Med. 2016: DOI: 10.1056/NEJMoa1600651

72. Jampol LM, Goldstein DA: Zika virus infection and the eye. JAMA Ophtalmol. 2016: doi:10.1001/jamaophthalmol.2016.0284

73. de Paula-Freitas B, de Oliveira-Dias JR, Prazeres J: Ocular findings in infants with microcephaly associated with presumed Zika virus congenital infection in Salvador, Brazil. JAMA Ophtalmol. 2016: doi: 10.1001/jamaophthalmol.2016.0267

74. Calvet G, Aquiar RS, Melo AS, et al: Detection and sequencing of Zika virus from amniotic fluid of fetuses with microcephaly in Brazil: a case study. Lancet Infect Dis. 2016: doi: 10.1016/S1473-3099(16)00095-5

75. Musso D, Baud D: Zika virus: time to move from case reports to case control. Lancet Infect Dis. 2016: doi:10.1016/ S1473-3099(16)00096-7

76. Oliveira-Melo AS, Malinger G, Ximenes R, et al: Zika virus intrauterine infection causes fetal brain abnormality and microcephaly: tip of the iceberg?. Ultrasound Obstet Gynecol. 2016; 47(1): 6-7.

77. Heymann DL, Hodgson A, Alpha-Sall Amadou, et al: Zika virus and microcephaly: why is this situation a PHEIC?. Lancet. 2016; 387(10020): 719-21.

78. Curtis Z, Matzen K, Neira-Oviedo M: Assessment of the impact of potential tetracycline exposure on the phenotype of Aedes aegypti OX513A: implications for field use. PLoS Negl Trop Dis. 2015: doi: 10.1371/journal. pntd.0003999

79. Santiago FW, Halsey ES, Slles C, et al: Long-Term artralgia after Mayaro virus infection correlates with sustaines pro-inflammatory cytokine response.PLoS Negl Trop Dis: 9(10):e0004104. doi:10.1371/journal.pntd.0004104

80. Napolea-Pego P, Gomes LP, Provance-Jr DW, et al: Mayaro Virus Disease. J Hum Retrovirol(2008) 1(3): 00018. DOI:10.15406/jhvrv.2014.01.00018

81. Subsecretaría de prevención y promoción de la salud: Lista actualizada de productos recomendados por el CENAPRECE para el combate de insectos vectores de enfermedades a partir del 2015. Secretaría de Salud. [Acceso: 20 de diciembre del 2015]. Disponible en: http://www.cenaprece.salud. gob.mx/programas/interior/vectores/descargas/pdf/ ListaActualizadaInsumosRecomendadosCENAPRECE2015. pdf 